Wacław Cockiewicz

Uniwersytet Jagielloński, Kraków

wcockiewicz@interia.pl

\title{
WARA OD MIOTŁY? \\ ODPOWIEDŹ NA POLEMIKĘ PROFESORA WŁADYSŁAWA MIODUNKI
}

Słowa klucze: glottodydaktyka, językoznawstwo stosowane, terminologia, język ojczysty, język obcy, dwujęzyczność

Keywords: language pedagogy, applied linguistics, terminology, native language, foreign language, bilingualism

Czuj się jak u siebie w domu - weź miotłę, pozamiataj. Obszerny artykuł polemiczny profesora Władysława Miodunki opublikowany w poprzednim (2 (16) 2013) numerze "LingVariów” w reakcji na moją propozycję usystematyzowania podstawowych terminów stosowanych w glottodydaktyce (ogłoszoną w numerze 1 (15) 2013) postrzegam jako swoisty konwers tego dowcipnego polskiego powiedzonka. Zaraz na samym wstępie mój znakomity adwersarz uświadamia mnie, że w glottodydaktyce bynajmniej nie jestem u siebie: „mimo że dla prof. Cockiewicza glottodydaktyka nie stanowi głównej specjalizacji, zamierza on porządkować «terminologiczny chaos» w glottodydaktyce" (Miodunka 2013: 275), informując równocześnie, że to jemu przede wszystkim należy się w tej dziedzinie status domownika, z czym nie sposób się nie zgodzić, zważywszy jego nieocenione i niekwestionowane zasługi dla rozwoju polskiej glottodydaktyki, co w moim najgłębszym przekonaniu zapewnia mu wręcz pozycję gospodarza. $Z$ tej właśnie pozycji profesor wyraża swoją dezaprobatę dla użytego przeze mnie sformułowania, wyrażającego diagnozę aktualnego stanu panującego w terminologii glottodydaktycznej: 
[...] mimo że zajmuję się glottodydaktyką od 40 lat, a glottodydaktyką polonistyczną od 35 lat, nie miałem dotąd wrażenia, że „,chaos terminologiczny”, czy raczej różnorodność terminologiczna, cechuje tylko glottodydaktykę (ibid.).

Jeśli osoba o takim autorytecie kwestionuje moją tezę, to mam niewątpliwie powód do niepokoju, ale i do myślenia. Niepokoję się więc i zaczynam myśleć. Najpierw myślę inspirowany owym niepokojem: czy na pewno jestem w glottodydaktyce tylko gościem, który w dodatku w obcym domu chwyta miotłę i próbuje zamiatać, wywołując konfuzję i oburzenie gospodarzy? Jednak przez 14 z górą lat mojej aktywności zawodowej zajmowałem się praktycznie glottodydaktyką: najpierw jako lektor w Bochum, potem jako lektor, a następnie tzw. Privatdozent w Getyndze, wreszcie już jako profesor (odpowiednio: językoznawstwa zachodniosłowiańskiego i polonistyki) w Lipsku i w Greifswaldzie, a trzy spośród moich publikacji książkowych (w tym habilitacyjna) bądź to w całości mają charakter bezpośrednio glottodydaktyczny, bądź też z takich inspiracji wyrastają. Mam świadomość, jak to niewiele w porównaniu z 40 latami i wszystkimi dokonaniami profesora Miodunki, ale mimo to sądziłem, że nawet to „niewiele” zjednuje mi jakieś skromne miejsce przy rodzinnym glottodydaktycznym stole. Być może jednak boleśnie się mylę. Mój polemista wydaje się wszakże dawać mi szansę, bo dalej pisze: „Zamiast mówić o «chaosie terminologicznym» w językoznawstwie, mówiłbym raczej o wielkim rozwoju tej nauki”. Z językoznawstwa zaś raczej trudno mnie wyprosić, jako że nawet mój stopień naukowy nazywa się „...w zakresie językoznawstwa polonistycznego".

Dalsza moja aktywność myślowa koncentruje się już na tezie wygłoszonej przez pana profesora. Całkowicie się z nią zgadzam. Tak, podobny chaos terminologiczny panuje w wielu dziedzinach nauk, zwłaszcza humanistycznych, a w lingwistyce powszechnie znany jest przykład nieszczęsnego terminu konotacja, który występuje aż w trzech znaczeniach: tym, jakie mu nadał Karl Bühler (1934) w dziedzinie składni, i dwóch w obrębie semantyki: w jej klasycznej wersji zainicjowanej przez Johna Stuarta Milla (1843) jako przeciwieństwo denotacji (Grzegorczykowa 1990: 14) oraz w sensie, jaki mu przypisał Charles E. Osgood (1952: 197-198). Z tezą się zgadzam, ale argumentu nie przyjmuję, bo nigdy nie twierdziłem, że jest inaczej, że to tylko przypadłość glottodydaktyki. Zgadzam się również z inną tezą profesora Miodunki: „że w przypadku wielu terminów trzeba ich rozumienie wyraźnie odnosić do kierunku badań, szkoły naukowej czy wręcz do ujęć teoretycznych wybitnego autora". Problem w tym, że tu właśnie tkwi różnica, która powoduje, że nad tamtymi chaosami można przejść do porządku dziennego, a nad tym w glottodydaktyce nie. Tamte są niegroźne, w każdym razie do pewnego stopnia. Przypominają homonimię/polisemię ${ }^{1} \mathrm{w}$ języku naturalnym, która z powodzeniem neutralizowana jest przez kontekst, gdyż ten

1 Z synchronicznego punktu widzenia nie sposób ustalić różnicę między polisemią a homonimią, na co zwraca między innymi uwagę John Lyons (1976: 448). 
jednoznacznie wskazuje, o które ze znaczeń chodzi. W przypadku homonimicznej terminologii funkcję kontekstu spełnia odniesienie do paradygmatu: nazwa teorii, w której termin funkcjonuje, względnie nazwisko „wybitnego autora”.

Terminy glottodydaktyczne, o których piszę, są nieprecyzyjne i niejednoznaczne $\mathrm{z}$ całkiem innego powodu. Nie są one mianowicie definiowane, lecz zamiast tego opisywane są prototypy zjawisk, do których się one odnoszą. Efekt takiego stanu rzeczy ilustrują podane w moim artykule przykłady: pokazują one, że wszystko, co choć trochę odbiega od stereotypu, wymyka się tym terminom. Żeby przytaczane przeze mnie za Ewą Lipińską formuły, traktowane przez nią (i przez samych ich autorów) jako definicje, w ogóle odpowiadały rzeczywistości, wymagają one kwantyfikujących selektywnie modyfikatorów typu najczęściej, zazwyczaj itp. Dla pełnej jasności muszę tu podkreślić, że zarzut, który formułuję, nie odnosi się tylko do definicji E. Lipińskiej, lecz do wszystkich „definiowanych” w taki sposób terminów glottodydaktycznych, także do dwóch definicji przytaczanych przez profesora Miodunkę za leksykografami francuskimi. Wszystkie one zamiast definiować w sposób klasyczny, umożliwiający precyzyjne różnicowanie, opisują prototypy. Definiowanie natomiast polega właśnie na różnicowaniu - kryterium definicji to differentia specifica. Moja propozycja systematyzująca nawiązuje bezpośrednio do tej klasycznej tradycji definiowania.

Zupełnie więc nie ma racji profesor Miodunka, kiedy pisze: „Proponowana przez Autora definicja zapewne nie spełnia cech klasycznej definicji, jakiej oczekuje on od innych" (Miodunka 2013: 277), gdyż ten swój zarzut odnosi on nie do definicji, lecz do mojego komentarza do niej i opiera go na tym, że w tym komentarzu (przedstawianym przez niego jako definicja) mówię o narodzie, a przecież „nie każda grupa ludzka ma socjologiczny status narodu" (ibid.). Dla definicji kwestia ta nie ma żadnego znaczenia, bo kryterium stanowi OPCJA, a czy ona będzie narodowa, etniczna, wspólnotowa czy po prostu ojczyźniana, to jest zupełnie drugorzędne. W podobny sposób polemista stara się zakwestionować zaproponowany przeze mnie termin język rodzimy. Tu kryterium stanowi SPOSÓB AKWIZYCJI - NATURALNY, PRZEZ NAŚLADOWNICTWO. Profesor Miodunka przytacza mój opisowy komentarz do tej definicji, który brzmi:

Język rodzimy to ten język, który poznajemy w sposób naturalny wraz z poznawaniem otoczenia (świata). Odbywa się to zazwyczaj w środowisku rodzinnym, rzadziej w innym (np. sierociniec, rodzina zastępcza etc.), a osobą, od której przejmuje się tę kompetencję, jest zazwyczaj matka, rzadziej inny członek rodziny lub opiekun/ka (Cockiewicz 2013: 206).

Następnie zaś formułuje taki oto „zarzut”: „Już w tej definicji zaskakuje brak ojca, jako drugiej, niezbędnej do poczęcia dziecka, części podstawowej rodziny, którą stanowią rodzice" (Miodunka 2013: 276). W tym miejscu szacunek i sympatia do mojego interlokutora nakazują mi wstrzymać się od komentarza. 
Zaproponowane przeze mnie rozumienie terminu język ojczysty, które - co należy przyznać - burzy dotychczasową tradycję, niepokoi W. Miodunkę i zapewne dlatego przeciwstawia mu on definicje dwóch renomowanych słowników francuskich, które przytacza we własnym tłumaczeniu. Jeśli jednak jego intencją jest powołanie się na autorytet dwóch znakomitych zagranicznych wydawców (Larousse’a i Jeana-Pierre'a Cuqa), to byłaby to próba zastosowania argumentum ad verecundiam, która wydaje się cokolwiek anachroniczna (nie na czasie) i, pozwolę sobie użyć neologizmu, anatopiczna (nie na miejscu). O ile sobie dobrze przypominam, argument $\mathrm{z}$ autorytetu był w dyskursie naukowym ostatni raz zastosowany bodaj w XVI w. w odniesieniu do Kopernikańskiej teorii heliocentrycznej.

Problem jednak jest i dotyczy przede wszystkim konfrontacji tego terminu z jego odpowiednikami w najpopularniejszych językach zachodnich. We wszystkich tych nazwach człon przymiotnikowy motywowany jest przez leksem matka: ang. mother tongue, franc. langue maternelle, hiszp. lengua materna, niem. Muttersprache. Nie bez związku z tym faktem bywa często błędnie pod względem słowotwórczym interpretowana nazwa polska, w której przymiotnik ojczysty kojarzony jest z pozorną bazą ojciec zamiast z właściwą ojczyzna. Rzeczywisty stosunek derywacyjny w przeciwieństwie do tego pozornego charakteryzuje zatem wyraźny brak proporcji: tam chodzi o język, który przejmuje się od matki - język matki, tu o język ojczyzny. Proporcję tę przywraca natomiast proponowany przeze mnie w tym właśnie znaczeniu termin język rodzimy. Istnieje do tego w międzynarodowej terminologii stosowny precedens: w języku rosyjskim całej serii zachodnich ,języków matczynych" odpowiada poдной язык, co dosłownie znaczy właśnie język rodzimy. Pozostaje jednak jeszcze kwestia międzynarodowych odpowiedników terminu język ojczysty w znaczeniu przeze mnie proponowanym. Najprostszym rozwiązaniem wydaje się analogiczne oparcie tych nazw o przymiotnikowe derywaty rzeczownika ojczyzna w odnośnych językach, a więc np. ang. homeland language, franc. langue de patrie, hiszp. idioma de patria, niem. Heimatsprache etc.

Dla jasności wypada jeszcze dodać, że przeciwstawiając definicję klasyczną opisowej, która polega na charakterystyce prototypu, nie odmawiam bynajmniej tej drugiej wartości naukowej. Zawiera ona bowiem wiele ważnych informacji na temat opisywanego zjawiska i jego różnych aspektów. Nie sprzyja natomiast precyzyjnemu odróżnianiu i systematyzacji terminów.

Jest taki recenzencki, niezbyt może oryginalny, ale wciąż z powodzeniem stosowany sposób na to, żeby pognębić autora: wytyka się mu, że nie przeczytał jakiejś ważnej książki dotyczącej tematu, na który się wypowiada. Chwyt ten stosuje się przeważnie w odniesieniu do młodych autorów i do stosunkowo nowych pozycji wydawniczych. Książka Krystyny Wróblewskiej-Pawlak Język - tożsamość - imigracja. O strategiach adaptacyjnych Polaków zamieszkałych we Francji w latach osiemdziesiąych XX wieku z roku 2004, której nieuwzględnienie zarzuca mi mój krytyk, raczej pozycją szczególnie nową nie jest, a i ja już swoje lata mam, więc przytaczana przez nią typologia 
Maurice’a van Overbeke’a jest mi znana. Nie rozumiem jednak, po co miałbym się odwoływać do jakichkolwiek typologii dwujęzyczności czy tym bardziej do 150 stron rozważań na jej temat w książce o języku, tożsamości i imigracji, kiedy celem moich dociekań jest uściślenie terminów, w tym wypadku odróżnienie z jednej strony dwu-/ wielojęzyczności (każdego typu), a z drugiej poliglotyzmu (też każdego typu, jeśli ktoś jakieś typy wyróżnił lub wyróżni)? W jaki sposób miałoby mi to „ułatwić dyskusję i zaproponowanie definicji określonego typu"?

Są także w polemicznym artykule profesora Miodunki wyraźnie samymi chyba tylko emocjami inspirowane oceny przypisujące mi intencje, których absolutnie nie miałem, nie mam i nie ma żadnych podstaw, żeby mi je przypisywać:

Zjawisko, o którym mowa, wiąże się z rozwojem dydaktyki języków w wielu krajach świata i dlatego krzywdzące dla polskich specjalistów jest mówienie o „terminologicznym chaosie" w glottodydaktyce, ponieważ sugeruje ono niepełną orientację w rozwoju tej części nauki (Miodunka 2013: 281).

Przeciwko tej niesprawiedliwej opinii muszę zdecydowanie zaprotestować. Moja konstatacja bynajmniej nie odnosi się do „polskich specjalistów”, tylko do stanu rzeczy w glottodydaktyce w ogóle, który charakteryzuje się brakiem precyzji stosowanych terminów, a już na pewno nie sugeruje ona czyjejkolwiek „niepełnej orientacji”. Jest dokładnie przeciwnie: to mój adwersarz mnie zarzuca (wprost, bez sugerowania) nieznajomość rzeczy - vide trzy akapity wyżej.

Do tej absolutnie bezpodstawnej, a dla mnie krzywdzącej tezy W. Miodunka powraca jeszcze raz na końcu swojego artykułu:

Część językoznawców, zajmujących się badaniem i opisem polszczyzny, wątpi w wartość teoretyczną i merytoryczną ustaleń glottodydaktyki polonistycznej. Echa takiego podejścia do glottodydaktyki pobrzmiewają też w artykule Cockiewicza. Byłoby bardzo dobrze, gdyby ta polemika zachęciła zainteresowanych do rozpoczęcia procesu rewizji tego stanowiska (ibid.: 282).

Pan profesor usłyszał echo, które nie tylko w moim artykule nie "pobrzmiewa”, ale wręcz odwrotnie: całkiem otwarcie brzmi w nim coś zupełnie przeciwnego. Stan, którego krytyka inspiruje mnie do przedstawienia mojej usystematyzowanej propozycji terminologicznej, odnoszę wyraźnie do glottodydaktyki w ogóle, a nie wyłącznie do tej polskiej. Większość definicji, które przytacza E. Lipińska, pochodzi przecież od niepolskich autorów, podobnie jak definicje francuskich leksykografów cytowanych przez W. Miodunkę. W moim artykule piszę zresztą wyraźnie:

Wszelkie tego typu dylematy biorą się stąd, że większość definicji podstawowych terminów glottodydaktyki - nie tylko E. Lipińskiej - posługuje się eklektycznymi, enumeratywnie stosowanymi kryteriami, czego konsekwencją jest opisywanie prototypów zamiast rzeczywistego definiowania terminów (Cockiewicz 2013: 205). 
Chyba tylko jakieś bardzo silne emocje mogły spowodować, że tak uważny czytelnik mógł tego nie dostrzec. A swoją drogą mam nieśmiałą nadzieję, że i mój skromny przyczynek należy do (szeroko rozumianych) „ustaleń glottodydaktyki polonistycznej".

Profesor Miodunka zdaje się zatem dostrzegać w moim tekście rzeczy, których tam nie ma, a nie zauważać tych, które tam są. Oto przykład:

Definiowanie terminu język ojczysty jest szczególnie skomplikowane, gdyż to połączenie wyrazowe jest używane często w języku mówionym, a także jako termin w kilku dyscyplinach naukowych. Dlatego rozsądnie postępuje ten, kto ogranicza cechy definicyjne do niezbędnego minimum, a definicję uzupełnia potrzebnym komentarzem, jak widzimy to w słownikach francuskich czy w słowniku Szulca (Miodunka 2013: 281).

Wypada mi tu nieskromnie zauważyć, że ten komplement dla słowników francuskich i Aleksandra Szulca mnie się, co najmniej również, należy, bo moje „niezbędne minimum" ogranicza się do jednej opozycji, która stanowi kryterium tak dyskretne i wystarczające, że nie wymaga wcale uzupełniania komentarzem.

Myślę, że polemiczna wypowiedź W. Miodunki znacznie zyskałaby na rzeczowości, gdyby było w niej więcej analitycznej i bezstronnej refleksji odnoszącej się do przedmiotu zamiast do osoby, a mniej emocji i postawy obronnej, zwłaszcza tam, gdzie żadnego ataku nie ma.

Do czego może prowadzić nadmiar emocji przy deficycie refleksji, pokazuje następujący przykład (abstrahując oczywiście od tego, co opisał Książę Biskup Warmiński w Monachomachii). Na zadysponowanej przez profesora Miodunkę (służbowo mojego przełożonego) dyskusji nad tym moim przyczynkowym artykułem na zebraniu kierowanej przez niego Katedry Języka Polskiego jako Obcego jedna z koleżanek oświadczyła - cytuję in extenso: „Jeśli jedynym pana celem było odróżnienie bi-/multilingwisty od poligloty, to pański artykuł nie ma sensu". Ksiądz profesor Tischner mawiał, że nerwy i myślenie są w nieustannym konflikcie tworzącym błędne koło: żeby się przestać denerwować, trzeba zacząć myśleć, ale żeby zacząć myśleć, trzeba się przestać denerwować. Gdyby moja koleżanka była wtedy w stanie wyrwać się z tego zaklętego kręgu, to być może zauważyłaby, że wystarczy wygłoszoną przez nią opinię uogólnić, żeby otrzymać taką oto tezę: „kiedy się mówi, nieważne jest, żeby dokładnie odróżniać od siebie rzeczy, o których się mówi - ważne, żeby mówić".

Polemicznie emocjonalna wypowiedź profesora Miodunki stanowi ważki a zapewne również reprezentatywny głos oceniający. Wniosek z niej jest dla mnie zdecydowanie negatywny: najbliższe środowisko moją propozycję odrzuca, a nawet ma mi ją za złe. Pozostaje mi liczyć w przyszłości na środowisko dalsze. A na razie muszę się jakoś pogodzić z faktem, że przyszedłem do swoich, ale swoi mnie nie przyjęli. Nemo propheta in patria sua. 


\section{Literatura}

BÜHLER K., 1934, Sprachtheorie, Jena.

Cockiewicz W., 2013, Jak uporzadkować terminologiczny chaos w glottodydaktyce i po co?, „LingVaria” VIII, nr 1, s. 201-213.

Grzegorczy Kowa R., 1990, Wprowadzenie do semantyki językoznawczej, Warszawa.

LiPIŃsKa E., 2003, Język ojczysty, język obcy, język drugi. Wstęp do badań dwujęzyczności, Kraków.

Lyons J., 1976, Wstęp do językoznawstwa, Warszawa.

Mill J.S., 1962, [1843], System logiki dedukcyjnej i indukcyjnej, Warszawa.

Miodunka W., 2013, O definiowaniu języków ojczystego i obcego oraz o „terminologicznym chaosie" w glottodydaktyce - polemicznie, „LingVaria” VIII, nr 2, s. 275-283.

OsGood CH.E., 1952, The nature and measurement of meaning, „Psychological Bulletin”, S. $197-237$.

\section{Hands off the broom? Reply to prof. Władysław Miodunka Summary}

This text is a reply to prof. Władysław Miodunka’s polemic on the proposition previously put forward by this author, to systematize the basic language pedagogical terminology. The opponent resents the use of the phrase "terminological chaos". The author explains why he had used it, and answers several other minor objections. In this case, terminological chaos results not from that one term has multiple meanings, as this is the relatively widespread situation in many disciplines, but from that the terms used in language pedagogy are not defined in the classical sense, and therefore do not discretely distinguish the respective phenomena. Instead, definitions describe prototypes. Adopted from cognitive linguistics, this custom has the undesirable effect that everything that is not prototypical, eludes the terminology - even if such descriptive definitions do provide many important pieces of information on the essence of the respective phenomena.

Od redakcji: Na tym dyskusję na łamach „LingVariów” zamykamy. 